\title{
KONJUNGSI TEMPORAL DALAM KUMPULAN CERITA RAKYAT MELAYU JAMBI TULISAN ISKANDAR ZAKARIA (ANALISIS WACANA)
}

\author{
Uli Wahyuni ${ }^{1}$, Nurshella Amhar Rasidah ${ }^{2}$ \\ Program Studi Pendidikan Bahasa dan Sastra Indonesia, \\ Fakultas Keguruan dan Ilmu Pendidikan, Universitas Batanghari, \\ Jambi \\ Uli09yumna@gmail.com \\ amharnurshella15@gmail.com
}

\begin{abstract}
This research is aimed at describing the forms and usage of temporal conjunction by using Indriani and Chaer theory. This research explains the forms and usage of temporal conjunction in the kumpulan cerita rakyat Melayu Jambi by Iskandar Zakaria. This research is qualitative descriptive. The data of this research is kumpulan cerita rakyat Melayu Jambi by Iskandar Zakaria (Discourse Analysis). The technique of data collection is by using documentation technique. The result of this research shows the description about the forms and usage of temporal conjunction in the Kumpulan Cerita Rakyat Melayu Jambi by Iskandar Zakaria (Discourse Analysis). Those forms are ketika, sewaktu, sementara, sebelum, setelah, and selagi. Those forms are specified based on the sequence of permulaan, waktu bersamaan, waktu berurutan, and waktu batas akhir in which each of them has their own function.
\end{abstract}

Keywords: Temporal Conjunction, Cerita Rakyat

1 Dosen Program Studi Pendidikan Bahasa dan Sastra Indonesia, Fakultas Keguruan dan Ilmu Pendidikan, Universitas Batanghari, Jambi

2 Mahasiswa Program Studi Pendidikan Bahasa dan Sastra Indonesia, Fakultas Keguruan dan Ilmu Pendidikan, Universitas Batanghari, Jambi

Konjungsi Temporal dalam Kumpulan Cerita Rakyat Melayu Jambi Tulisan Iskandar Zakaria (Analisis Wacana) 


\section{PENDAHULUAN}

Bahasa salah satu hal penting yang perlu dipelajari karena mempunyai fungsi dan peranan yang besar dalam kehidupan manusia. Bahasa sangat dibutuhkan sebagai sarana untuk menyampaikan sesuatu kepada orang lain yang bisa dipahami dan dimengerti oleh lawan bicara. Bahasa digunakan masyarakat sebagai alat pergaulan antarsesama dan alat untuk menyampaikan sebuah pemikiran (Rofii dan Hasibuan, 2019). Bahasa dapat digunakan baik secara lisan maupun tulisan. "Bahasa secara lisan dapat digunakan sebagai alat interaksi sosial di masyarakat, sedangkan bahasa secara tulisan dapat digunakan untuk menggantikan komunikasi lisan yang dapat disampaikan melalui media" (Tasyakhur, 2018: 9).

Tanpa bahasa $\begin{gathered}\text { seseorang tidak } \\ \text { mengekspresikan, }\end{gathered}$
mampu menyampaikan suatu pesan. Pemanfaatan potensi bahasa sebagai alat komunikasi dapat dilihat dalam berbagai sendi kehidupan kita di antaranya, dunia pendidikan, pemerintahan, dan media massa termasuk dalam karya sastra (Pernando dan Rahima, 2017:1). Hal inilah yang melatarbelakangi peneliti mengambil objek kajian bahasa karena pentingnya fungsi bahasa sebagai sarana dalam bersastra salah satunya sastra lisan.

Manusia dapat menggunakan bahasa sebagai alat komunikasi dalam aktivitasnya di masyarakat. Komunikasi dapat dilakukan secara verbal maupun nonverbal. Komunikasi verbal dilakukan secara lisan sedangkan komunikasi nonverbal dilakukan dengan bahasa isyarat atau simbol-simbol. Komunikasi verbal melalui lisan dapat dilakukan dengan media tulisan, gambar, atau media massa. Media tulis memiliki wacana-wacana dari bentuk penggunaan bahasa sebagai alat komunikasi. Selain itu, bahasa juga berfungsi sebagai alat untuk menyampaikan ide, gagasan yang bersifat imajinatif seperti di dalam sastra.

Sastra memiliki wacana yang mengandung unsur-unsur konjungsi. "Kata sambung untuk menghubungkan sebuah kalimat dengan kalimat lain disebut konjungsi. Kata sambung berfungsi untuk menyambung, merangkai, dan menghubungkan kata antarparagraf (Kridalaksana dalam Junaiyah dan Arifin, 2010: 36)". Jenisjenis konjungsi adalah konjungsi subordinatif, konjungsi koordinatif, dan konjungsi temporal. Dalam hal ini peneliti mengkaji tentang konjungsi temporal.

Konjungsi temporal merupakan kata yang berfungsi untuk menghubungkan kalimat sebagai keterangan waktu. Konjungsi temporal dapat digunakan dalam penulisan cerita rakyat. Cerita rakyat adalah cerita yang hidup di masyarakat dan disampaikan secara turun-temurun yang memiliki arti dan pesan dalam cerita tersebut. Salah satu tradisi yang akan terus hidup selagi masih mempunyai makna dalam kehidupan masyarakat. Peneliti ingin mengetahui bagaimana bentuk, makna, dan penggunaan konjungsi temporal dalam cerita rakyat. Kurang tepatnya bentuk konjungsi di dalam penulisan cerita rakyat menjadi salah satu kendala bagi pembaca sehingga pembaca sulit memahami isi cerita rakyat tersebut baik isi maupun makna. Pentingnya kajian 
tentang konjungsi ini terkait dengan tingkat pemahaman pembaca terkait isi cerita rakyat tersebut. Berdasarkan hasil pengamatan peneliti, masih banyak pemakaian konjungsi yang membuat pembaca sulit memahami sebuah cerita. Seperti contoh berikut:

Waktu batu itu meninggi sore itu, ribut pula seisi desa

Pemakaian konjungsi temporal pada kutipan cerita di atas menyulitkan pembaca untuk memahami. Hal inilah yang membuat peneliti mengkaji lebih dalam tentang konjungsi temporal. Berdasarkan hasil observasi peneliti di Museum Siginjai Jambi, peneliti diarahkan oleh pihak Museum dan peneliti diberikan buku tentang ceritacerita rakyat yang berasal dari berbagai daerah. Buku tersebut memiliki 11 cerita dari 9 daerah yang ada di Provinsi Jambi salah satunya Kabupaten Kerinci. Peneliti merasa tertarik dengan cerita Puti Senang dan Tupai Jenjang yang berasal dari Kabupaten Kerinci. Alasan peneliti memilih cerita rakyat dari Kabupaten Kerinci sebagai judul penelitian karena peneliti bukan putri asli dari daerah tersebut sehingga peneliti terarik untuk memilih cerita rakyat yang berjudul Puti Senang dan Tupai Jenjang dan peneliti ingin mengetahui kebudayaankebudayaan yang ada di Kabupaten Kerinci salah satunya cerita rakyat. Cerita rakyat merupakan kearifan lokal yang harus dilestarikan dan dikembangkan dari pergeseran globalisasi agar tidak punah. Oleh sebab itu kita sebagai masyarakat dan penerus bangsa harus mengembangkan salah satu kekayaan yang kini mulai tenggelam dengan cerita- cerita yang lebih menarik perhatian pembaca.

Penulis memilih cerita rakyat sebagai objek penelitian bahasa yang merupakan salah satu dari karya sastra, dikarenakan cerita rakyat banyak menggunakan konjungsi khususnya temporal seperti kata ketika, waktu, sewaktu, saat, tatkala, selagi, sebelum, sesudah, setelah, sejak, semenjak, dan sementara. Selain itu penulis ingin memberikan pengetahuan tentang bentuk dan penggunaan konjungsi temporal khususnya dalam cerita rakyat karena dalam membuat sebuah cerita rakyat terkadang penulis keliru atau kurang memahami bagaimana penempatan konjungsi itu sendiri. Berdasarkan uraian di atas dapat disimpulkan beberapa alasan peneliti memilih Konjungsi Temporal dalam Kumpulan Cerita Rakyat Melayu Jambi Tulisan Iskandar Zakaria (Analisis Wacana) yang mencakup hal-hal berikut.

1. Pentingnya penelitian fungsi bahasa sebagai sarana dalam bersastra salah satunya sastra lisan.

2. Pentingnya mengembangkan sastra lisan berupa cerita rakyat dari Kabupaten Kerinci yang harus dilestarikan dan dikembangkan dari pergeseran globalisasi agar tidak punah.

3. Peneliti melihat kurangnya penelitian tentang konjungsi temporal dalam cerita rakyat maupun dalam pembahasan yang lain.

4. Pentingnya mengetahui bentuk dan kegunaan konjungsi khususnya temporal agar tidak menimbulkan 
kesalahpahaman makna terhadap pembaca.

Konjungsi temporal merupakan konjungsi yang menyatakan hubungan waktu. Menurut Chaer (2015: 102) bahwa "Konjungsi temporal adalah konjungsi yang menghubungkan waktu antara dua buah peristiwa atau tindakan; antara dua buah klausa pada sebuah kalimat majemuk atau dalam sebuah paragraf'. Seperti yang dikemukakan oleh Kusrini (2008: 109) bahwa "Konjungsi temporal menjelaskan hubungan waktu antara dua hal atau peristiwa. Konjungsi dibedakan lagi menjadi konjungsi temporal sederajat dan konjungsi temporal tidak sederajat". Sedangkan menurut Indriani (2011: 24) bahwa "Konjungsi temporal adalah konjungsi hubungan waktu yang jika klausa sematanya menyatakan waktu terjadinya peristiwa atau keadaan yang dinyatakan dalam klausa utama".

Folklor diartikan sebagai adatistiadat tradisional dan cerita rakyat yang diwariskan secara turun-temurun, dan tidak dibukukan. Menurut Endraswara (2013: 2) bahwa "Folklor sebagian kebudayaan suatu koletif, yang tersebar dan diwariskan secara turun-temurun, di antara kolektif macam apa saja, secara tradisional dalam versi yang berbeda, baik dalam bentuk lisan maupun contoh yang disertai dengan gerak isyarat atau alat pembantu pengingat". Dengan demikian, pengertian folklor adalah bagian dari kebudayaan yang disebarkan dan diwariskan secara tradisional, baik dalam bentuk lisan maupun contoh yang disertai dengan gerak isyarat atau alat pembantu pengingat.
Danandjaja (2002: 2) menyatakan bahwa "Folklor adalah sebagian kebudayaan suatu kolektif, yang tersebar dan diwariskan turun-temurun, di antara kolektif macam apa saja, secara tradisional dalam versi yang berbeda, baik dalam bentuk lisan maupun contoh atau alat pembantu pengingat". Berbeda pendapat dengan Leach (dalam Endraswara, 2013: 2) bahwa folklor merupakan "A lively fossil which refuses to die (sebuah fosil hidup yang menolak untuk mati)". Karena folkor merupakan cerminan diri dan kebiasaan manusia secara kolektif, maka mengungkap folklor sama halnya menyelami misteri indah manusia.

Sastra lisan merupakan bagian dari suatu kebudayaan yang tumbuh dan berkembang di tengah-tengah masyarakat dan diwariskan secara turun temurun. Menurut Danandjaja (dalam Inriani, 2017: 167) bahwa "Sastra lisan merupakan bagian dari kehidupan sastra yang memiliki posisi sangat penting dalam masyarakat". Menurut Astika dan Nyoman (2014: 2) "Sastra lisan adalah kesusastraan yang mencakup ekspresi kesusastraan warga suatu kebudayaan yang disebarkan dan diturun-temurunkan (dari mulut ke mulut)". Menurut Endraswara (2018: 1) "Sastra lisan adalah berbagai tuturan verbal yang memiliki ciri-ciri sebagai karya sastra pada umumnya, yang meliputi puisi, prosa, nyanyian, dan drama lisan".

Cerita rakyat pada dasarnya merupakan cerita lisan yang telah lama hidup dalam tradisi suatu masyarakat. Cerita rakyat adalah bagian dari folklor yang tergolong dalam folklor lisan. 
Penyebaran cerita rakyat pada uumnya bersifat tradisional yang tumbuh dan berkembang serta menyebar secara lisan dari satu generasi ke generasi berikutnya dalam suatu masyarakat. Cerita rakyat merupakan karya sastra yang berbentuk lisan, yang merupakan hasil tuturan turun-temurun, dan merupakan warisan kebudayaan yang hidup di tengah-tengah masyarakat. Cerita rakyat yang tersebar melalui lisan dan kisahnya bersifat anonim yang waktu dan nama penciptanya pun sudah tidak diketahui lagi. Oleh karena itu cerita rakyat merupakan salah satu bagian dari folklor. Menurut Bunanta (dalam Aminah, 2016: 30) "Cerita rakyat adalah salah satu bentuk folklor lisan. Cerita rakyat merupakan bagian dari sejarah dan budaya suatu bangsa. Umumnya, cerita rakyat mengisahkan tentang terjadinya berbagai hal, seperti terjadinya alam semesta, tempat, maupun suatu peristiwa penting”. Menurut Danandjaya (2002: 4) "Cerita rakyat merupakan salah satu bentuk sastra rakyat yang bersifat anonim. Cerita rakyat menjadi milik bersama dari kolektif tertentu karena penciptanya yang pertama sudah tidak diketahui lagi". Sedangkan menurut Mukti (2008: 49) "Cerita rakyat merupakan salah satu bentuk karya sastra yang lahir dari tradisi lisan yang diturunkan dari generasi satu ke generasi berikutnya".

Cerita rakyat Melayu Jambi adalah cerita yang turun-temurun dari masyarakat Melayu Jambi. Dari hasil kajian penulis ada beberapa cerita rakyat yang sudah dibukukan antara lain cerita rakyat Melayu Jambi Puti Senang dan
Tupai Jenjang yang berasal dari Kabupaten Kerinci tulisan Iskandar Zakaria. Berdasarkan pendapat di atas dapat disimpulkan bahwa cerita rakyat merupakan karya sastra berbentuk lisan, yang merupakan hasil tuturan dari satu generasi ke generasi berikutnya dan merupakan warisan kebudayaan yang hidup ditengah-tengah masyarakat serta bagian dari folklor.

Wacana merupakan satuan yang ditelaah dalam bidang analisis wacana. "Analisis wacana merupakan cabang ilmu bahasa yang digunakan untuk menganalisis suatu unit bahasa yang lebih besar daripada kalimat (Kartomiharjo, 1992: 1)". Menurut Muis (2014: 111) "Analisis wacana adalah telaah mengenai aneka fungsi (pragmatik bahasa)".

\section{METODE PENELITIAN}

Jenis penelitian yang digunakan dalam penelitian ini adalah pendekatan kualitatif. Menurut Rukajat (2018: 6) "Pendekatan kualitatif merupakan prosedur penelitian yang menghasilkan data deskriptif berupa kata-kata tertulis maupun lisan dari orang-orang dan perilaku yang diamati. Penelitian kualitatif lebih menekankan pada bahasa sebagai sarana penelitiannya". Menurut Sugiyono (2017:15) "Penelitian kualitatif adalah penelitian yang digunakan untuk meneliti pada kondisi objek yang alamiah di mana peneliti adalah sebagai instrumen kunci, teknik pengumpulan data dilakukan secara trianggulasi (gabungan), analisis data bersifat induktif, dan hasil penelitian kualitatif lebih menekankan makna dari 
generalisasi”. Penelitian ini termasuk penelitian kualitatif karena data yang akan dianalisis adalah kata-kata yaitu konjungsi temporal dalam kumpulan cerita rakyat Melayu Jambi tulisan Iskandar Zakaria.

Penelitian ini menggunakan metode deskriptif. Data deskriptif diperoleh dari data yang berupa teks. Menurut Sukmadinata (dalam Fitrah, 2017: 36) "Penelitian deskriptif adalah suatu metode penelitian yang ditujukan untuk menggambarkan fenomenafenomena yang ada, yang berlangsung saat ini atau saat lampau". Penelitian ini dimaksudkan untuk mendeskripsikan bentuk dan kegunaan konjungsi temporal dalam kumpulan cerita rakyat Melayu Jambi tulisan Iskandar Zakaria (Analisis Wacana).

Data merupakan hal yang penting dalam penelitian karena data merupakan hal utama dalam melakukan penelitian. "Data adalah segala bentuk informasi, fakta, dan realitas yang terkait dengan apa yang diteliti atau dikaji (Ibrahim dalam Desnawati, 2017: 41)". Berbeda pendapat dengan Dewi (2015: 34) "Data adalah bentuk jamak dari datum, yang dapat diartikan sebagai informasi yang diterima yang bentuknya dapat berupa angka, kata-kata, atau dalam bentuk lisan dan tulisan lainnya".

Data primer yang diperoleh langsung dari sumber asli. Menurut Sugiyono (2017: 22) mengungkapkan "Data primer adalah data yang langsung memberikan data kepada pengumpul data". Jadi data primer ini berupa kalimat yang mengandung konjungsi temporal dalam kumpulan cerita rakyat melayu Jambi tulisan Iskandar Zakaria.

Sumber data adalah sumber darimana suatu data diperoleh. Sumber data dalam penelitian ini adalah Kumpulan Cerita Rakyat Melayu Jambi tulisan Iskandar Zakaria. Kumpulan Cerita Rakyat diterbitkan oleh Dinas Kebudayaan dan Pariwisata Provinsi Jambi, Jambi. Kumpulan Cerita Rakyat Melayu Jambi tulisan Iskandar Zakaria mrupakan cetakan pertama tahun 2008. Jumlah halaman 125 halaman. Selain kumpulan cerita rakyat Melayu Jambi, sumber data lain dalam penelitian ini yaitu berupa buku-buku yang menyangkut pembahasan tentang konjungsi temporal dalam Kumpulan Cerita Rakyat Melayu Jambi tulisan Iskandar Zakaria (Analisis Wacana).

Teknik pengumpulan data merupakan cara peneliti mengumpulkan suatu data yang digunakan untuk kelengkapan penelitian. Menurut Sugiyono (2017: 308) “Teknik pengumpulan data merupakan langkah yang paling utama dalam penelitian, karena tujuan utama dari penelitian adalah mendapatkan data". Berdasarkan pendapat diatas bahwa teknik pengumpulan data merupakan proses dalam penelitian yang bertujuan untuk mendapatkan data.

Teknik pengumpulan data termasuk bagian penting dalam sebuah penelitian. "Teknik pengumpulan data dalam penelitian ini menggunakan teknik dokumentasi dengan rekayasa peneliti (Sugiyono, 2017: 329)". Dokumentasi digunakan untuk mengumpulkan datadata penelitian pada Kumpulan Cerita 
Rakyat Melayu Jambi tulisan Iskandar Zakaria (Analisis Wacana). Teknik ini dilakukan melalui beberapa langkah, sebagai berikut.

1. Peneliti membaca keseluruhan dengan kritis dan teliti setiap kalimat Kumpulan Cerita Rakyat Melayu Jambi tulisan Iskandar Zakaria.

2. Peneliti mengulang membaca dan menandai kalimat-kalimat yang mengandung konjungsi temporal dari setiap kalimat Kumpulan Cerita Rakyat Melayu Jambi tulisan Iskandar Zakaria.

3. Peneliti mengumpulkan data sesuai dengan bentuk-bentuk yang berkaitan dengan konjungsi temporal. Bentukbentuk tersebut ketika, waktu, sewaktu, saat, tatkala, selagi, sebelum, sesudah, setelah, sejak, semenjak, sementara.

4. Peneliti mendeskripsikan kegunaan yang berkaitan dengan bentuk-bentuk konjungsi temporal.

Analisis data pada penelitian ini menggunakan analisis data kualitatif. Menurut Anggito (2018: 235) “Analisis data merupakan kaidah penelitian yang wajib dilakukan oleh semua peneliti, karena sebuah penelitian tanpa analisis hanya akan melahirkan sebuah data mentah yang tidak mempunyai arti". Setelah peneliti mengumpulkan data dan mengelompokkan data tersebut dari Kumpulan Cerita Rakyat Melayu Jambi tulisan Iskandar Zakaria (Analisis Wacana). Peneliti melanjutkan tindakan yakni menganalisis data yang dikumpulkan.

Data yang telah dikelompokkan itu diuraikan sesuai dengan metodenya.
Dalam penelitian ini, penulis menggunakan metode distribusional untuk mengolah data yang telah diperoleh. Metode distribusional adalah metode analisis bahasa yang memerikan unsur-unsur bahasa dalam satuan yang lebih besar (Djajasudarma dalam Rahima, 1994: 16).

Untuk menganalisis data dengan menggunakan metode distribusional memerlukan teknik tertentu. Dalam penelitian ini teknik-teknik yang digunakan untuk menganalisis data meliputi teknik subtitusi, ekspansi, dan permutasi.

\section{HASIL DAN PEMBAHASAN}

Penelitian ini membahas tentang bagaimana bentuk dan penggunaan konjungsi temporal dalam Kumpulan Cerita Rakyat Melayu Jambi tulisan Iskandar Zakaria. Adapun yang di dapat dalam hasil penelitian mengenai bentuk dan penggunaan konjungsi temporal dalam Kumpulan Cerita Rakyat Melayu Jambi melalui pendekatan struktural. Maka untuk memperoleh konjungsi temporal dalam Kumpulan Cerita Melayu Jambi terdiri dari 68 kutipan yang mencakup 5 bentuk konjungsi temporal yaitu ketika, sewaktu, selagi, sementara, sebelum, dan setelah dari 2 aspek yang diteliti. Cerita tersebut akan peneliti singkat menjadi Cerita Puti Senang (CPS) dan Cerita Tupai Jenjang (CPJ). Hal tersebut dapat dijelaskan sebagai berikut:

1. Bentuk Konjungsi Temporal
'Ketika' dalam Kumpulan Cerita
Rakyat Melayu Jambi tulisan
Iskandar Zakaria




\section{Bentuk konjungsi temporal} ketika yang telah terlampir terdapat 22 kutipan data dari 2 cerita rakyat yaitu cerita rakyat Puti Senang dan Tupai Jenjang. Sesuai dengan teori untuk menganalisis bentuk-bentuk konjugsi temporal yang dikemukakan oleh (Indriani, 2011: 24 dan Djajasudarma (dalam Rahima 1994: 17). Berikut adalah penjelasan lebih lanjut mengenai kutipan data yang telah di analisis berdasarkan teori yang menjadi acuan penulis.

1b) "Ketika batu besar itu mulai terangkat, si Kulut bertanya pada kakaknya”. (CPS, 3)

1a) "Batu besar itu mulai terangkat, sewaktu si Kulut bertanya pada kakaknya”. (CPS, 3)

38a) "Begitu juga ketika sedang hamil dan melihat tupai dikebunnya, doa yang terbetik juga dalam hatinya". (CTJ, 27)

38b) "Begitu juga sewaktu sedang hamil dan melihat tupai dikebunnya, doa yang terbetik juga dalam hatinya". (CTJ, 27)

Dalam kutipan tersebut terdapat konjungsi kesewaktuan ketika. Bentuk konjungsi ketika dapat bersubtitusi dengan sewaktu. Hal tersebut ditunjukkan pada kalimat (1a) dan (1b) dalam cerita rakyat Puti Senang, (38a) dan (38b) dalam cerita rakyat Tupai Jenjang. Bentuk konjungsi ketika dalam kutipan tersebut untuk menunjukkan waktu yang bersamaan.

15a) "Suatu hari, ketika mereka sedang meratap, tiba-tiba terdengar suara gemuruh dari arah langit”. (CPS, 14) 15b) "Suatu hari, seraya mereka sedang meratap, tiba-tiba terdengar suara gemuruh dari arah langit”. (CPS, 14)

Dalam kutipan tersebut terdapat konjungsi kesewaktuan ketika. Bentuk konjungsi ketika dapat bersubtitusi dengan seraya. Hal tersebut ditunjukkan pada kalimat (15a) dan (15b) pada cerita rakyat Puti Senang. Bentuk konjungsi ketika dalam kutipan tersebut untuk menunjukkan waktu yang bersamaan.

43a) "Akan halnya Ratu Lindung Bulan, ketika raja masih dalam pencarian kelapa cungkil dan tiram, dia telah melahirkan anaknya". (CTJ, 27)

43b) "Akan halnya Ratu Lindung Bulan, selama raja masih dalam pencarian kelapa cungkil dan tiram, dia telah melahirkan anaknya". (CTJ, 27)

Dalam kutipan tersebut terdapat konjungsi kesewaktuan ketika. Bentuk konjungsi ketika dapat bersubtitusi dengan selama. Hal tersebut ditunjukkan pada kalimat (43a) dan (43b) pada cerita rakyat Tupai Jenjang. Bentuk konjungsi ketika dalam kutipan tersebut untuk menunjukkan waktu yang bersamaan.

\section{Bentuk Konjungsi Temporal 'Sewaktu' dalam Kumpulan Cerita Rakyat Melayu Jambi tulisan Iskandar Zakaria}

Bentuk konjungsi temporal sewaktu yang telah terlampir terdapat 1 kutipan data dari cerita rakyat Puti Senang. Sesuai dengan teori untuk menganalisis bentuk-bentuk konjugsi temporal yang dikemukakan oleh (Indriani, 2011: 24 dan Djajasudarma (dalam Rahima, 1994: 17). Berikut 
adalah penjelasan lebih lanjut mengenai kutipan data yang telah di analisis berdasarkan teori yang menjadi acuan penulis.

16a) "Sewaktu Puti Senang bersama batu kendaraannya, nenek Rubiah yang menjaga pintu langit mendengar ayam betina berkotekkotek". (CPS, 9)

16b) "Ketika Puti Senang bersama batu kendaraannya, nenek Rubiah yang menjaga pintu langit mendengar ayam betina berkotek-kotek". (CPS, 9)

Dalam kutipan tersebut terdapat konjungsi kesewaktuan sewaktu. Bentuk konjungsi sewaktu dapat bersubtitusi dengan ketika. Hal tersebut ditunjukkan pada kalimat (16a) dan (16b) pada cerita rakyat Puti Senang. Bentuk konjungsi sewaktu dalam kutipan tersebut untuk menunjukkan waktu yang bersamaan.

\section{Bentuk Konjungsi Temporal 'Selagi' dalam Kumpulan Cerita Rakyat Melayu Jambi tulisan Iskandar Zakaria}

Bentuk konjungsi temporal selagi yang telah terlampir terdapat 1 kutipan data dari cerita rakyat Tupai Jenjang. Sesuai dengan teori untuk menganalisis bentuk-bentuk konjugsi temporal yang dikemukakan oleh (Indriani, 2011: 24 dan Djajasudarma (dalam Rahima, 1994: 17). Berikut adalah penjelasan lebih lanjut mengenai kutipan data yang telah di analisis berdasarkan teori yang menjadi acuan penulis.

44a) "Sebelum gunung betuah meletus, selagi lembah Kerinci disebut laut, yang manusianya tinggal di renahrenah perbukitan, ada satu legenda yang masih hidup sampai sekarang, dan sering diceritakan orang-orang tua kepada anak cucunya". (CTJ, 20)

44b) "Sebelum gunung betuah meletus, selama lembah Kerinci disebut laut, yang manusianya tinggal di renah-renah perbukitan, ada satu legenda yang masih hidup sampai sekarang, dan sering diceritakan orang-orang tua kepada anak cucunya”. (CTJ, 20)

Dalam kutipan tersebut terdapat konjungsi kesewaktuan selagi. Bentuk konjungsi selagi dapat bersubtitusi dengan selama. Hal tersebut ditunjukkan pada kalimat (44a) dan (44b) pada cerita rakyat Tupai Jenjang. Bentuk konjungsi selagi dalam kutipan tersebut untuk menunjukkan waktu yang bersamaan.

\section{Bentuk Konjungsi Temporal 'Sementara' dalam Kumpulan Cerita Rakyat Melayu Jambi tulisan Iskandar Zakaria}

Bentuk konjungsi temporal sementara yang telah terlampir terdapat 2 kutipan data dari cerita rakyat Puti Senang dan 2 dari cerita rakyat Tupai Jenjang. Sesuai dengan teori untuk menganalisis bentuk-bentuk konjugsi temporal yang dikemukakan oleh (Indriani, 2011: 24 dan Djajasudarma (dalam Rahima, 1994: 17). Berikut adalah penjelasan lebih lanjut mengenai kutipan data yang telah di analisis berdasarkan teori yang menjadi acuan penulis.

18a) "Sementara Puti Senang berada di langit, kedua orang tua Puti Senang selalu menangis, menyesali perbuatannya”. (CPS, 14) 
18b) "Selagi Puti Senang berada di langit, kedua orang tua Puti Senang selalu menangis, menyesali perbuatannya". (CPS, 14)

45a) "Rupanya sementara hulubalang itu bertempur, Ratu menyuruh menukar makanan itu dengan yang baru”. (CTJ, 30)

45b) "Rupanya selagi hulubalang itu bertempur, Ratu menyuruh menukar makanan itu dengan yang baru”. (CTJ, 30)

Dalam kutipan tersebut terdapat konjungsi kesewaktuan sementara. Bentuk konjungsi sementara dapat bersubtitusi dengan selagi. Hal tersebut ditunjukkan pada kalimat (18a) dan (18b) dalam cerita rakyat Puti Senang, (45a) dan (45b) dalam cerita rakyat Tupai Jenjang. Bentuk konjungsi sementara dalam kutipan tersebut untuk menunjukkan waktu yang bersamaan.

\section{Bentuk Konjungsi Temporal 'Sebelum' dalam Kumpulan Cerita Rakyat Melayu Jambi tulisan Iskandar Zakaria}

Bentuk konjungsi temporal sebelum yang telah terlampir terdapat 2 kutipan data dari cerita rakyat Puti Senang dan 6 dari cerita rakyat Tupai Jenjang. Sesuai dengan teori untuk menganalisis bentuk-bentuk konjungsi temporal yang dikemukakan oleh (Indriani, 2011: 24 dan Djajasudarma (dalam Rahima, 1994: 17). Berikut adalah penjelasan lebih lanjut mengenai kutipan data yang telah di analisis berdasarkan teori yang menjadi acuan penulis.

19a) "Sebelum ibu si Bujang Tandang sampai di rumah nenek, nenek itu segera turun kehalaman". (CPS, 12)

47a) "Sebelum gunung Batuah meletus, selagi Lembah Kerinci disebut laut, yang manusianya tinggal di renahrenah perbukitan, ada satu legenda yang masih hidup sampai sekarang, dan sering diceritakan orang-orang tua kepada anak cucunya". (CTJ, 20)

Dalam kutipan tersebut terdapat konjungsi kesewaktuan sebelum. Bentuk konjungsi sebelum tidak dapat bersubtitusi dengan bentuk konjungsi yang lain. Bentuk konjungsi sebelum dalam kutipan tersebut untuk menunjukkan waktu berurutan.

\section{Konjungsi Temporal 'Setelah' dalam Kumpulan Cerita Rakyat Melayu Jambi tulisan Iskandar Zakaria}

Bentuk konjungsi temporal setelah yang telah terlampir terdapat 16 kutipan data dari cerita rakyat Puti Senang dan 16 kutipan data dari cerita rakyat Tupai Jenjang. Sesuai dengan teori untuk menganalisis bentuk-bentuk konjungsi temporal yang dikemukakan oleh (Indriani, 2011: 24 dan Djajasudarma (dalam Rahima, 1994: 17). Berikut adalah penjelasan lebih lanjut mengenai kutipan data yang telah di analisis berdasarkan teori yang menjadi acuan penulis.

24a) "Dengan sedikit upacara ritual, baju tersebut dapat dipinjamkan, setelah ayah Puti Senang memenuhi beberapa syarat yang ditentukan”. (CPS, 16)

24b) "Dengan sedikit upacara ritual, baju tersebut dapat dipinjamkan, 
sesudah ayah Puti Senang memenuhi beberapa syarat yang ditentukan". (CPS, 16)

53a) "Gunung Batuah yang dulunya tinggi, setelah kejadian itu jadi terbenam dan membentuk sebuah danau, bernama danau Kerinci”. (CTJ, 20)

53b) "Gunung Batuah yang dulunya tinggi, sesudah kejadian itu jadi terbenam dan membentuk sebuah danau, bernama danau Kerinci”. (CTJ, 20)

Dalam kutipan tersebut terdapat konjungsi kesewaktuan setelah. Bentuk konjungsi setelah dapat bersubtitusi dengan sesudah. Hal tersebut ditunjukkan pada kalimat (24a) dan (24b) dalam cerita rakyat Puti Senang dan (53a) dan (53b) dalam cerita rakyat Tupai Jenjang. Bentuk konjungsi setelah dalam kutipan tersebut untuk menunjukkan waktu berurutan.

36a) "Setelah persiapan lengkap, maka berangkatlah kedua laki-laki itu terbang ke langit". (CPS, 16)

36b) "Begitu persiapan lengkap, maka berangkatlah kedua laki-laki itu terbang ke langit”. (CPS, 16)

56a) "Setelah selesai, dipakailah liontin dan anting-anting dari emas bermata mutiara, gelang emas bersisik ular dan cincin emas permata intan”. (CTJ, 23)

56b) "Begitu selesai, dipakailah liontin dan anting-anting dari emas bermata mutiara, gelang emas bersisik ular dan cincin emas permata intan". (CTJ, 23)

Dalam kutipan tersebut terdapat konjungsi kesewaktuan setelah. Bentuk konjungsi setelah dapat bersubtitusi dengan begitu. Hal tersebut ditunjukkan pada kalimat (36a) dan (36b) dalam cerita rakyat Puti Senang dan (56a) dan (56b) dalam cerita rakyat Tupai Jenjang. Bentuk konjungsi setelah dalam kutipan tersebut untuk menunjukkan waktu berurutan.

55a) "Setelah memperkenalkan diri dan sedikit berbincang-bincang tentang negeri masing-masing, perempuan yang berbaya utusan Tuanku yang Bertuah Raja Tuan itu memperhatikan sang Ratu, baik wajahnya, tutur bahasanya, cara berpakaian, tata ruang dan peralatan di rumah Ratu itu" (CTJ, 22)

55b) "Sehabis memperkenalkan diri dan sedikit berbincang-bincang tentang negeri masing-masing, perempuan yang berbaya utusan Tuanku yang Bertuah Raja Tuan itu memperhatikan sang Ratu, baik wajahnya, tutur bahasanya, cara berpakaian, tata ruang dan peralatan di rumah Ratu itu”. (CTJ, 22)

Dalam kutipan tersebut terdapat konjungsi kesewaktuan setelah. Bentuk konjungsi setelah dapat bersubtitusi dengan sehabis. Hal tersebut ditunjukkan pada kalimat (55a) dan (55b) dalam cerita rakyat Tupai Jenjang. Bentuk konjungsi setelah dalam kutipan tersebut untuk menunjukkan waktu berurutan.

\section{SIMPULAN}

Berdasarkan hasil penelitian yang telah dijelaskan, maka dapat disimpulkan konjungsi temporal dalam kumpulan 
cerita rakyat Melayu Jambi tulisan Iskandar Zakaria (analisis wacana) yang mencakup sebagai berikut.

1. Bentuk-bentuk konjungsi temporal yang terdapat dalam kumpulan cerita rakyat Melayu Jambi Puti Senang dan Tupai Jenjang ditemukan bentukbentuk ketika, waktu, sewaktu, saat, tatkala, selagi, sebelum, sesudah, setelah, sejak, semenjak, sementara. Bentuk-bentuk tersebut dikelompokkan berdasarkan waktu yang ditentukan yakni waktu permulaan, waktu bersamaan, waktu berurutan, dan waktu batas akhir.

2. Penggunaan bentuk-bentuk konjungsi temporal mencakup 9 (sembilan) kegunaan, yang meliputi:

1) Ketika digunakan untuk menunjukkan waktu yang sama antara kejadian, tindakan, atau peristiwa yang terjadi dalam klausa pada kalimat majemuk.

2) Sewaktu secara umum dapat digunakan untuk menggantikan konjungsi ketika.

3) Selagi digunakan untuk menghubungkan menyatakan durasi waktu yang sama yang terjadi antara dua buah klausa dalam sebuah kalimat majemuk.

4) Semetara secara umum dapat digunakan untuk menggantikan konjungsi selagi.

5) Sebelum digunakan untuk menghubungkan menyatakan waktu kejadian, peristiwa, atau tindakan pada klausa utama terjadi 'sebelum' terjadinya kejadian, peristiwa, atau tindakan pada klausa bawahan.

6) Sesudah digunakan untuk menghubungkan menyatakan waktu kejadian, peristiwa, atau tindakan pada klausa utama terjadi 'sesudah' terjadinya kejadian, peristiwa, atau tindakan pada klausa bawahan.

7) Setelah secara umum dapat digunakan untuk menggantikan konjungsi sesudah.

8) Semenjak digunakan untuk menghubungkan menyatakan waktu kejadian, peristiwa, atau tindakan pada klausa utama terjadi 'berawal' ketika kejadian, peristiwa, atau tindakan pada klausa bawahan terjadi.

9) Sementara digunakan untuk menghubungkan menyatakan kesamaan waktu antara kejadian, peristiwa, atau tindakan yang terjadi pada kalimat pertama dengan kalimat kedua yang mengikutinya.

Sudah ditemukan penggunaan konjungsi temporal yang tepat dalam cerita rakyat, sehingga dengan tatanan bahasa yang baik dapat memudahkan pembaca untuk memahami maksud dari penggunaan konjungsi temporal tersebut.

\section{SARAN}

Berdasarkan simpulan tersebut, maka terdapat beberapa saran yang dapat dikemukakan pada bagian ini, sebagai berikut.

1. Bagi mahasiswa dalam menulis karya sastra atau nonsastra sebaiknya mahasiswa lebih memperhatikan 
penggunan konjungsi, karena penggunaan konjungsi dalam penulisan dapat berpengaruh bagi pembaca.

2. Banyaknya pemakaian konjungsi temporal di dalam cerita rakyat bisa memberikan informasi untuk pengembangan kosa kata daerah kepada masyarakat di luar dari Melayu Jambi, sehingga kosa kata daerah tersebut dapat dipahami dan digunakan untuk berinteraksi dengan masyarakat setempat.

3. Disarankan kepada Dinas Pendidikan dan Pariwisata untuk memberikan pelatihan kepada penggiat budaya untuk meningkatkan pemahaman tentang cerita rakyat.

4. Cerita rakyat ini dapat dijadikan bagian dari kegiatan seni budaya di daerah tersebut untuk meningkatkan pariwisata, misalnya lomba membaca cerita rakyat.

\section{DAFTAR PUSTAKA}

Aminah, Nur. (2016). Nilai-nilai Pendidikan Cerita Rakyat dalam Buku Sastra Lisan Lampung Karya A. Effendi Sanusi dan Implikasinya dalam Pembelajaran Bahasa Lampung di Sekolah Menengah Pertama. Skripsi. Bandar Lampung: Universitas Lampung.

Anggito, Albi dan Johan Setiawan. (2018). Metodologi Penelitian Kualitatif. Jawa Barat: CV Jejak.

Astika, I Made dan I Nyoman Yasa. (2014). Sastra Lisan; Teori dan Pnerapannya. Yogyakarta: Graha Ilmu.

Chaer, Abdul. (2015). Sintaksis Bahasa Indonesia. Jakarta: Rineka Cipta.
Danandjaja, James. (2002). Foklor Indonesia: Ilmu Gosip, Dongeng, dan lain-lain. Jakarta: Pustaka Utama Grafiti.

Desnawati. (2017). Analisis Kohesi Gramatikal Pelajaran Wacana Buku Teks Siswa Bahasa Indonesia Kurikulum 2013 Kelas 3 SMA Tahun 2014 (Suatu Kajian Wacana). Skripsi. Jambi: Universitas Batanghari Jambi.

Dewi, Ratna. (2015). Efektivitas Model Pembelajaran Kooperatif Tipe Team Assisted Individualization (TAI) Terhadap Hasil Belajar Matematika pada Siswa Kelas X SMK Negeri 1 Kota Jambi. Skripsi. Jambi: Universitas Batanghari Jambi.

Endraswara, Suwardi. (2018). Antropologi Sastra Lisan: Prespektif, Teori, dan Praktik Pengkajian. Jakarta: Yayasan Pustaka Obor Indonesia.

Fitrah, Muh dan Luthfiyah. (2017). Metodologi Penelitiani. Jawa Barat: CV Jejak.

Indriani, Yulia Anjas. (2011). Penggunaan Konjungsi Bahasa Indonesia. Skripsi. Purwokerto: Universitas Muhammadiyah Purwokerto.

Inriani, Kethy. (2017). Nilai Kearifan Lokal dalam Legenda Cerita Rakyat Muntok: Sebuah Kajian Pendidikan Karakter. Skripsi. Palembang: Universitas Sriwijaya.

Kartomiharjo, Soeseno. (1992). Analisis Wacana dan Penerapannya. Malang: Institut Keguruan dan Ilmu Pendidikan Malang.

Kusrini, Idda Ayu. (2008). Bahasa Indonesia 1 SMP Kelas VII. Jakarta: Yudhistira. 
Muis, Sitti Fauziah. (2014). Analisis Wacana dalam Bahasa Indonesia. Jurnal Shautut Tarbiyah.

Mukti, H. Adanhuri dan Gaman Sakti. (2008). Sejarah Kabupaten Tebo. Muara Tebo:

Pernando, E., \& Rahima, A. (2017). Analisis Kohesi Leksikal dalam Majalah Patriotik LPM Universitas Batanghari Edisi XVI Juli-September Tahun 2016. Aksara: Jurnal Ilmiah Pendidikan Bahasa dan Sastra Indonesia, 1(1), 1-10.

Rahima, Ade. Numeralia Bahasa Melayu Jambi: Kajian Morfosintaksis. Tesis. Bandung: Universitas Padjajaran.

Rofii, Afif. dan Hasibuan, Rizka Rani (2019) Interferensi Bahasa Batak Mandailing dalam Tuturan Berbahasa Indonesia Pada Acara Parpunguan Masyarakat Mandailing Kota Jambi. Aksara. Aksara: Jurnal Ilmiah Pendidikan Bahasa dan Sastra Indonesia Vol. 3 No. 1 April 2019 aksara.unbari.ac.id/index.php/aks ara/article/download/94/50.

Rukajat, Ajat. (2018). Pendekatan Penelitian Kualitatif. Sleman: CV Budi Utama.

Sugiyono. (2017). Metode Penelitian Pendidikan. Bandung: Alfabeta.

Tasyakhur, Muhammad. (2018). Analisis Fungsi Konjungsi Koordinatif Bahasa Jawa Ngoko dalam Ungkapan Sehari-hari Masyarakat Desa Tambang Emas Kecamatan Pemenang Selatan Kabupaten Merangin (Kajian Morfosintaksis). Skripsi. Jambi: Universitas Batanghari. 